\title{
A Study on the Characteristics and Trends of Sustainable Fashion through Esthetica at London Fashion Week
}

\author{
Hye Eun $\mathrm{Kim}^{\dagger}$ \\ Fashion Womenswear, Royal College of Art; London, United Kimdom
}

\begin{abstract}
The purpose of this study is to investigate sustainable fashion flows and to outline their characteristics by analysing Esthetica as the largest trade-based sustainable fashion exhibition in the UK. Most of the researchers have focused on its ethical meaning rather than on fashionable criteria or marketable value. This pioneer work could be helpful in order to plan and study sustainable fashion flows. The research method is to identify characteristics of sustainable fashion trends through literature reviews and case studies focused on the UK, Esthetica events and participating brands. The following results were obtained. Upcycling suggests the extension of a product's lifecycle, a trend on the increase. Transparency is the crucial issue in sustainable fashion. Estethica shows that nurturing sustainable brands is one effective way of boosting the sustainable industry, as well as encouraging the production of sustainable products. Sustainable fashion has come to be included in mainstream fashion in terms of aesthetics and commercial competitiveness. Finally, sustainable fashion highlights quality of garments. Thus, Esthetica shows the present of sustainable fashion and its future, that is, sustainable fashion not just as a trend but a lifestyle for both its consumers and the industry. As the sustainable industry is a growing sector, it would be useful to carry out separate in-depth case studies on leading sustainable brands and qualitative aspects.
\end{abstract}

Key words : Esthetica, sustainable fashion, upcycling, price transparency, ethical trading

\section{Introduction}

If industrialisation has brought people a more comfortable life, its accompanying mass production and consumption has led to environmental damage and social imbalance, thus raising the issue of sustainability. Sustainability encompasses the concerns of economic growth, environmental protection and social equality (McDonough \& Braungart, 2002). It is particularly important in the fashion sector, where the production of garments requires a great amount of material and labour, while tons of waste are also created not only in the making process but also when clothes are thrown away after being worn.

One important and practical response to this problem is represented by Estethica, a sustainable fashion showcase within London Fashion Week (hereafter, LFW) which is a preview of the latest fashion trends and one of the world's leading trade-based events of this kind together with New York, Milan and Paris Fashion Weeks. Estethica has exacting criteria for participants: their products should be eco-friendly as well as commercial, to attract both manufacturers and customers (The British Fashion Council, 2014a). The presence of Estethica makes Fashion Week an effective platform to display cutting-edge trends in the commodity

$\uparrow$ Corresponding author; Hye Eun Kim

Tel. +82-10-7162-5434

E-mail: hyk0010@hotmail.com as well as the ethics spheres, attracting both buyers and the press.

There are several academic studies on the subject of sustainable fashion. Most of the researchers focus on its ethical meaning rather than on fashionable criteria or marketable value (Farrer, 2011; Kim \& Lee, 2006; Yoo, 2012). Many of these studies also deal with the development of fashion design according to different concepts of sustainability, such as recycling and upcycling (Choi \& Kim, 2012; Jeong, 2012), or the use of organic materials (Kim et al., 2007); some other studies are about strategy and education for sustainable fashion (Kim, 2013; Nam, 2011; Niinimaki \& Hassi, 2011; Woodham, 2010) others still, on consumer behaviour related to sustainable fashion (Hong \& Kim, 2014; Pears, 2006; Yoon, 2013) finally, a number of case studies concern particular areas, such as upcycling, or regions, such as the UK (Kim, 2007; Kwan, 2012). However, there has been no research as yet about sustainable fashion as a trend, analysed through a world-leading Fashion Week. This is why sustainable fashion is not a transient fad anymore. Thus, it needs to consider sustainable fashion as a fashion commodity which is influenced by trend.

This research aims to examine the characteristics and trends of sustainable fashion through Esthetica at London Fashion Week. It can help understand the commercial and ethical meanings of sustainable fashion, as well as its aesthetic and trendsetting values.

Literature reviews and case studies focused on the UK, Esthetica events, and participating brands, have been carried out to identify 
the characteristics of sustainable fashion movements. Literature reviews examine the historical aspects of sustainability, as well as definitions of sustainable fashion. Events and brands in Esthetica, from 2009 SS to the present, are analysed according to objective facts, such as items displayed, participating period, each brand's sustainability principle and its year of establishment. Although the launch of Esthetica was in 2006, there are no relevant published or accessible records from that time, so the analysis dates from SS 2009. The materials examined are press releases, the London Fashion Week website and brands' websites.

\section{Sustainability in Fashion}

\subsection{The definition of sustainability and its development}

The word 'sustainable', as defined by the Centre for Sustainable Fashion at the London College of Fashion (2008), refers to "harnessing resources ethically and responsibly without destroying social and ecological balance". Because people cannot live without using materials and resources, they need to do this with care, keeping in mind the environmental and social effects of their behaviours. Concern about the environment was first brought to the public's attention by the book Silent Spring by Rachel Carson (1964), in which the writer warned of the scientific conceit that had caused chemical damage through recklessness in the use of insecticides and herbicides all over the USA. The term sustainable was first used together with development by the UN General Assembly, which established the World Commission on Environment and Development (WCED) in 1983; this, in turn, published the report 'Our Common Future in 1987. The word sustainable was used in the context of public goods being in danger; it was said that sustainable development would be based on "the needs of the present without compromising the ability of future generations to meet their own needs" (Smith \& Rees, 1998). Agenda 21, a voluntary action plan for sustainable development, which followed the UN Conference on Environment and Development (UNCED) held in Rio de Janeiro, Brazil, in 1992, proposed to open a new global partnership for sustainable development; in that year, sustainable development was incorporated into the UN's action plan. Under this scheme, every industrial sector had to be responsible for the environment and society (United Nations Division for Sustainable Development, 1992). In 2005, the EU implemented a law to the effect that electronics manufacturers were responsible for their own end-of-life processes (Sander et al., 2007). In his 2007 documentary, An Inconvenient Truth, Al Gore, former US Vice President, underlined the seriousness of global warming and the need for sustainability, which helped him earn a Nobel Prize for drawing the public's attention to this issue (Runice, 2014).

\subsection{The environmental and social effects of the fashion industry}

Sustainable clothing magnifies the positive and softens the negative impacts of fashion on the environment, society and the economy through its supply and value chains (DEFRA, 2010).

The fashion industry is globally worth over $£ 500$ billion and employs approximately 26 million people. However, in the UK alone, 2 million tonnes of clothing were consumed in 2006 at a cost of $£ 23$ billion. This is a growing concern because of fast fashion or discount fashion clothing accounting for one fifth of the UK market, with its share having doubled over the last 8-10 years. This causes environmental problems because a great deal of wearable and usable clothes are discarded, whilst social imbalance is indicated by the prevalence of sweatshops and labour exploitation in underdeveloped countries (DEFRA, 2010). According to Sahni (2009), the fashion industry is the second largest consumer of water in the world (the agricultural industry is the first). During the manufacturing process, $15 \%$ more cloth is ordered than is actually

Table 1. Sustainability issues in the fashion industry

\begin{tabular}{lll}
\hline Processing stages & Issues (Suggestions and problems regarding the issues) \\
\hline Raw material & Suggesting issues & $\begin{array}{l}\text { Renewable or non-renewable material (sustainable alternatives), fair trade, textile certification, } \\
\text { customer care, end-of-life box }\end{array}$ \\
\cline { 2 - 3 } Design & Problematic issues & Water use, land use, cotton issues, wet process \\
\hline Production & Suggesting issues & $\begin{array}{l}\text { Supply chain, social standards certifications, purchasing practices, the World Fair Trade Organisation } \\
\text { (WFTO) }\end{array}$ \\
\hline $\begin{array}{l}\text { Packing and } \\
\text { transportation }\end{array}$ & Suggesting issues & $\begin{array}{l}\text { Packing and branding, , transportation (using local supply, reducing weight and volume to optimise } \\
\text { transportation) }\end{array}$ \\
\cline { 2 - 3 } Consumer use & Problematic issues & Packing waste \\
\hline End of life & Suggesting issues & Second life, recyclability, biodegradability \\
\hline
\end{tabular}


needed for the production of an adult-sized garment (Borrini-Feyerabend et al., 2007). This obviously increases costs and the amount of waste produced.

Sustainable design considers every stage in a product's lifecycle. Anya Hindmarch, designer, brand founder and the mind behind the I Am Not A Plastic Bag initiative (providing supermarkets with reusable bags), defines sustainable fashion in terms of sourcing materials locally, provided that they do not harm the environment at any stage in their lifecycle, i.e., by recycling them and cutting down on transportation times and costs (Friedman, 2014). Table 1 illustrates the main sustainability issues in the fashion industry (The British Fashion Council, 2008).

In raw material, sustainability concerns materials used in garment making and their consuming process: how much water is used to produce fabrics involving cropping, farming, etc. Designers are responsible for creating long-lasting, functional products, as well as minimising waste during making. Resources can be redesigned in order to reuse the whole of a product, thus producing zero waste. This expression originated from the Zero Waste International Alliance in 2004, according to which: "Zero Waste is a goal that is ethical, economical, efficient and visionary, to guide people in changing their lifestyles and practices to emulate sustainable natural cycles, where all discarded materials are designed to become resources for others to use. Zero Waste means designing and managing products and processes to systematically avoid and eliminate the volume and toxicity of waste and materials, conserve and recover all resources, and not burn or bury them. Implementing Zero Waste will eliminate all discharges to land, water or air that are a threat to planetary, human, animal or plant health.” (The Zero Waste International Alliance, 2004). Thus, zero waste is about minimising not only the leftovers but also the materials discarded during the making process. Sourcing transportation and manufacturing locally saves money and natural resources (such as fuel), whilst reducing air pollution from exhaust fumes.

\section{The Background to Sustainable Fashion in the UK}

\subsection{Sustainable fashion in the UK}

The UK has a long history of sustainability. It led the Industrial Revolution in the mid- $18^{\text {th }}$ century, where the wool and textile factories played a central role along with coal mining and processing. As a pioneer of industrialisation, the UK started considering issues such as quality of life and the impact of the environment on society earlier than other countries. Today, the UK plays a central role in developing sustainable products, including fashion. This is the result of collaboration between the government, companies, and schools.

In particular, governmental organisations such as DEFRA (Department for Environment, Food and Rural Affairs), the Design Council, the Fashion Council and the Crafts Council have led the way in promoting sustainability. In 1986, the Design Centre held the Green Designer, a ground-breaking exhibition on eco-sustainability, in London, dedicated to 'green' product design (PicassoMio, 2014). It not only showcased eco-friendly products but also sent a strong message to the business world and the consumer community on the effects of current consumption behaviours on the environment. The year 2006 saw Well Fashioned: Eco Style in the $U K, a$ series of exhibitions held by the Design Council at different UK venues and covering a broad range of issues (from manufacturing and technology to education for designers and customers), which led to the fashion industry playing a key role in sustainability. DEFRA's policy guidelines on sustainability include Sustainable Clothing Action Plan in 2010 and Sustainable Clothing Roadmap, launched in 2007 and implemented in 2011. The City of London's continuous work in the area of sustainability has included launching a 'Green Guide' for the fashion industry (DEFRA, 2010).

Oxfam, one of the best-known aid agencies in the world, bases its work on recycling, fair trade and fair labour, which places it at the forefront of the sustainability cause. The charity opened its first shop in Oxford in 1948: this was effectively the first charity shop in the world; it is also known for having raised funds to alleviate poverty after World War II through donated items ranging from false teeth to various kinds of stuffed animals and even a houseboat. Oxfam now works on a range of sustainability issues including climate change, third-world debt and aid, health, education and trade (Oxfam, 2014).

The Centre for Sustainable Fashion (CFS) at the London College of Fashion has taken part in research, education and consultation for sustainable business. In collaboration with government departments and organisations such as DEFRA and the British Council, the CFS published research on the Shared Talent India Online Sourcing Toolkit in 2010, helping designers to better understand sustainable textile suppliers in India.

Given its early recognition of the importance of sustainability and the well-organised projects resulting from the collaboration of government, companies and schools, the UK is emerging as one of the most developed countries in terms of sustainable fashion. Indeed, according to The Co-operative Bank's annual Ethical Consumerism Report (2010), sustainable products which include clothing and cosmetics make the fastest growing sector in the UK, having increased by $29 \%$ from the previous year and totalling $£ 1.8$ 
billion.

\subsection{Estethica at London Fashion Week}

Fashion Week showcases trends by relating to their trade value. Sustainable fashion should not only be eco-friendly but also commercial, in order to attract both manufacturers and customers. Here, Fashion Week is one effective platform to show sustainable fashion as a commodity.

The UK is one of the leading countries in fashion with its London Fashion Week (LFW) and LFW is among the top four Fashion Weeks in the world (the others being Milan, New York and Paris). Agenda 21, a voluntary action plan, has turned out many worldclass designers such as Alexander McQueen, John Galliano and Vivienne Westwood.

Estethica is organised by the British Fashion Council (BFC) as part of LFW. It is the biggest eco-fashion event in the UK and is continuing to grow. LFW shows the latest trends and is attended by important fashion buyers and press from all over the world. Further, LFW and Estethica's fastidious criteria admit only some sustainable companies to participate. Estethica was founded in 2006 with 13 brands by BFC and sponsored by the UK retailer Monsoon; over the past seven years it has supported 108 international designers from 29 countries (The British Fashion Council, 2014). Estethica consists of four sections: Fair Trade, Ethical Trading, Recyclable Textiles and Organic/Man-made Biodegradable Textiles. Fair trade is a market-based approach to help producers in developing countries to trade on a more equitable level. Its focus is especially on exporting to developed countries products such as handicrafts, coffee, sugar, tea, cotton, wine, chocolate, flowers and gold (Brough, 2008). Ethical trading means improving the working lives of people across the globe who make or grow consumer goods. Recyclable textiles and clothes can be made into upcycled clothing. Organic/man-made biodegradable textiles reduce the harm to the environment at every stage of their lifecycle.

\section{Case Study}

\subsection{The sustainable brands and events participating in Esthetica}

Table 2 shows brands and their main characteristics in Esthetica, from 2009 SS to the present. These are examined on the basis of press releases, the London Fashion Week website and brands' websites.

The categories shown in Table 2 correspond to Esthetica criteria: Fair trade, Ethical Trading, Recyclable Textiles and Organic/Manmade Biodegradable Textiles. Here, Local Sourcing and Manufacturing is added as part of Ethical Trading because it supports local craftspeople for a balanced development of the small and largescale industry. Not only that, but also this local sourcing is environmentally meaningful; it reduces transportation times and costs, thus saving natural resources and reducing air pollution.

Table 2 shows Estethica's sustainable brands' various items and methods, as well as multiple ways of using sustainability. Since its launch in 2006, Estethica products were ready-to-wear clothes, bags and hats. However, now Estethica also covers eyewear, footwear, lingerie, and jewellery. Sustainable methods have become varied and sophisticated. Many brands originally focusing on fair trade, organic or recycled materials are now using less harmful dyeing methods, such as AZO-free or low-impact dyes; Ada Zanditon, Emesha, Ivana Basilotta, etc. In upcyling, they use not only throwaway or leftover fabric but also regenerated material such as Polyamide, a fibre extracted from fishing nets; Auria.

Estethica's brands endeavour to apply all the possible sustainable methods in multiple sectors. Lingerie brand Charini is a case in point, as it stakes its assets on fair trade, ethical trading and recyclable textiles: it uses traditional Sri Lankan environmentfriendly manufacturing methods, 'luxury reclaimed materials', hand-woven silks and lace, high-quality fabrics from reputed carbon-accredited factories (thus nurturing traditional local crafts), whilst avoiding 'elastics, plastics, underwire and harmful dying' (Charini, 2014). Every stage of the process, from raw materials to finished products and their after-life as materials again, is monitored according to strict sustainability principles and practices. The diversity and multiplicity of brands featured by Estethica covers most of the fashion sectors.

\subsection{Outstanding features of brands}

Many Estethica brands practise upcycling by using left-over, throw-away fabrics. Upcycling emphasises quality in the recycling process. The term, upcycling was first recorded by Reiner Pilz of Pilz GmbH in an article by Thornton Kay of Salvo in 1994, as opposed to down-cycling. Recycling can minimize waste by saving the energy and materials needed to create a new product. However, most recycled goods are downgraded. This can be seen in recycled paper or recycled plastic. Conversely, upcycling concentrates on quality, by involving re-manufacturing or refurbishment. This can be achieved by the use of new technology, such as nanotechnology or biotechnology. Since 2010, From Somewhere has collaborated with Speedo, the world's leading swimwear brand. In 2008, Speedo launched its revolutionary Speedo LZR Racer suit. Before FINA (Federation Internationale de Natation), the world's swimming governing body, decided to prohibit full-body suits in January 2010, these suits had helped to break 91 world swimming records. The surplus and all unsold stock were donated to charitable causes: 
Table 2. Estethica brands from SS 2009 to SS 2015

\begin{tabular}{|c|c|c|c|c|c|c|c|c|c|c|c|c|c|c|c|c|}
\hline & & & & & & & & & & & & & & & Criteria & \\
\hline Brand & $\begin{array}{l}09^{\circ} \\
\text { ss }\end{array}$ & & & & & & & & & & & & $\begin{array}{c}\text { Fair Trade } \\
\text { (material } \\
\text { focus) }\end{array}$ & $\begin{array}{l}\text { Ethical } \\
\text { Trading } \\
\text { (labour } \\
\text { focus) }\end{array}$ & $\begin{array}{c}\text { Recycling } \\
\text { Textiles }\end{array}$ & $\begin{array}{c}\text { Organic / man } \\
\text { made } \\
\text { biodegradable } \\
\text { textiles }\end{array}$ \\
\hline Ada Zanditon & & $\sqrt{ } \checkmark$ & 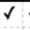 & $\sqrt{v}$ & $\sqrt{v}$ & $\sqrt{v}$ & $\sqrt{v}$ & $\checkmark$ & $\checkmark$ & $\checkmark$ & & & 0 & & & 0 \\
\hline Anatomy & & $\checkmark$ & & & & & & & & & & & & & & \\
\hline Antonello & & $\checkmark$ & & & & & & & & & & & & & & \\
\hline Article.23 & 1 & $\checkmark$ & & & & & & & & & & & $\circ$ & 0 & & 0 \\
\hline Auria & & & & & & & & $\checkmark$ & & $\checkmark$ & & $\checkmark$ & & & 0 & \\
\hline Beautiful Soul London & & & & & & & & & $\checkmark$ & $\checkmark$ & & & & & & \\
\hline Beyond Skin & & $\checkmark$ & & & & & & & & & & & & & & $\circ$ \\
\hline Bottletop & & & & & & & & & & $\checkmark$ & $\checkmark v$ & $\checkmark$ & & & 0 & \\
\hline Butcher Couture & $\checkmark$ & $\checkmark$ & & & & & & & & & & & & & & 0 \\
\hline Carla Fernandez & & & & & & & & $\checkmark$ & & & & & & $\circ$ & & \\
\hline Cangiari-Emerging Talents & & & & & & & & & & & $\checkmark$ & & & & & 0 \\
\hline $\operatorname{CDC}$ & & $\checkmark$ & & & & & & & & & & & & & & \\
\hline Charini & & & & & & & & $\checkmark$ & & & & $\checkmark$ & 0 & 0 & & 0 \\
\hline Christopher Raeburn & & & $\checkmark$ & $\checkmark$ & & $\checkmark$ & $\checkmark \checkmark$ & & & & & $\checkmark$ & & & 0 & \\
\hline Ciel & d, & $\checkmark$ & & & $\checkmark$ & $\mathrm{v}$ & $\checkmark$ & & & & & & 0 & & 0 & 0 \\
\hline Del Forte & & $\checkmark$ & & & & & & & & & & & & & 0 & 0 \\
\hline Devika Dass-Emerging & & & & & & & & & & & $\checkmark$ & & 0 & & & 0 \\
\hline Dr. Noki & & & & & $\checkmark$ & $v$ & $\checkmark$ & & & & & & & & 0 & \\
\hline Eden Diodati & & & & & & & & & & & & $\checkmark$ & & 0 & & \\
\hline Eloise Grey & $\checkmark$ & $\checkmark$ & & & & & & & & & & & & & & 0 \\
\hline Element 23 & & & & & & & & & & & & & & & & \\
\hline Emesha & & & & $\checkmark v$ & $\checkmark v$ & $\checkmark v$ & $r$ & & & & & & & 0 & 0 & 0 \\
\hline Enamore & $\checkmark$ & $\checkmark$ & & & & & & & & & & & & & 0 & 0 \\
\hline Environmental Justice & $\checkmark$ & $\checkmark$ & & & & & & & & & & & 0 & & & 0 \\
\hline Fifi Bijoux & $\checkmark$ & $\checkmark$ & & & & & & & & & & & 0 & & & \\
\hline FlaviaLaRocca-Emerging & & & & & & & & & & & $\checkmark v$ & $\checkmark$ & & & & \\
\hline From Somewhere & & $\checkmark v$ & $\checkmark$ & $\checkmark v$ & $\checkmark v$ & $\checkmark v$ & $r$ & & & & & & & & 0 & \\
\hline $\mathrm{G}=9.8$ & $\checkmark$ & & & & & & & & & & & & & & 0 & 0 \\
\hline Goodone & $\checkmark$ & $\checkmark v$ & $\checkmark$ & $\checkmark v$ & $\checkmark v$ & $\checkmark \checkmark$ & $\checkmark \checkmark$ & & $\checkmark$ & & & & & & 0 & \\
\hline Henrietta Ludgate & & & $\checkmark$ & $\checkmark v$ & $\checkmark v$ & $\checkmark v$ & $v$ & $\checkmark$ & $\checkmark$ & & & & & 0 & & \\
\hline Hetty Rose & & & & & & & & & & & & & & & 0 & \\
\hline Honest by. Bruno & & & & & & & & $\checkmark$ & & & & & & & & 0 \\
\hline Ignes & a & & & & & & & & & & & & 0 & 0 & & \\
\hline Ivana Basilotta & & $\checkmark$ & & & & & & & & & & & & & 0 & 0 \\
\hline Izzy Lane & a & $\checkmark$ & & & & & & & & & & & & 0 & & \\
\hline Jacob James & & & & & $\checkmark$ & $v$ & & & & & & & & & 0 & \\
\hline Joanna Cave & & & & $\checkmark v$ & $\checkmark v$ & $\checkmark \checkmark$ & $\checkmark \checkmark$ & $\checkmark$ & & & & & 0 & & 0 & \\
\hline Junky Styling & & & $\checkmark$ & $\checkmark v$ & $\checkmark v$ & $\checkmark \checkmark$ & $r$ & $\checkmark$ & & & & & & & 0 & \\
\hline Katherine Hamnett & & & & & & & & & & & & & 0 & 0 & & 0 \\
\hline Katie Jones-Emerging & & & & & & & & & & & & & & & 0 & \\
\hline Katrien Van Hecke & & & & & & & & & $\checkmark$ & $\checkmark$ & $\checkmark$ & & & & & \\
\hline Kumvana Gomani & & & & & r & $v$ & $\checkmark$ & & & & & & & 0 & 0 & \\
\hline Liora Lassalle & & & & & & & & & $\checkmark$ & $\checkmark$ & & & & & 0 & \\
\hline Lorico & & & & & & & & $\checkmark$ & & & & & & & & 0 \\
\hline Little Glass & & & & & s & $r$ & & & & & & & & & & \\
\hline Lost Property of & & & & & & & & & & $\checkmark$ & & & & & 0 & \\
\hline Louise de Testa- & & & & & & & & & & & $\checkmark v$ & $\checkmark$ & & & & \\
\hline Lucy Tammam & $\checkmark$ & & & & & & & & & & & & & & 0 & 0 \\
\hline Lu Flux & & & & & v & $v$ & $\checkmark$ & & & & & & & & 0 & \\
\hline Makepiece & & $\checkmark \checkmark$ & $\checkmark$ & $\checkmark \checkmark$ & $\checkmark$ & $v$ & & $\checkmark$ & & & & & & 0 & & 0 \\
\hline Mark Liu & & $\checkmark$ & & & & & & & & & & & & & 0 & 0 \\
\hline Maxjenny (art fashion & & & & & v & $\mathrm{v}$ & $\checkmark$ & $\checkmark$ & & & & & & & 0 & 0 \\
\hline Mich Dulce $\times$ Zacarias & & & & & & & & $\checkmark$ & $\checkmark$ & $\checkmark$ & $\checkmark v$ & $\checkmark$ & & 0 & 0 & \\
\hline Michelle Lowe Holder & & & & $\checkmark v$ & $\checkmark v$ & $\checkmark \checkmark$ & $r$ & & & & & & & & 0 & \\
\hline Minna (Hepburn) & 4 & $\checkmark$ & & & & & & & & & & & & & 0 & 0 \\
\hline Nahui Ollin & & $\checkmark$ & & & & & & & & & & & 0 & 0 & 0 & \\
\hline Nina Dolcetti & $\checkmark$ & $\checkmark$ & & & & & & & & & & & & & 0 & \\
\hline Noir & a & $\checkmark$ & & & & & & & & & & & 0 & 0 & & 0 \\
\hline NUMANU & & $\checkmark$ & & & & & & & & & & & & & & \\
\hline Oxfam & $\checkmark$ & $a v$ & $\checkmark$ & $r v$ & $\checkmark$ & & & & & & & & & & 0 & \\
\hline Pachacuti & & & $\checkmark$ & $\checkmark v$ & $\checkmark v a r a r a b$ & $\checkmark \checkmark$ & $r$ & $\checkmark$ & $\checkmark$ & $\checkmark$ & $\checkmark v$ & $\checkmark$ & 0 & 0 & & \\
\hline Partimi & & & & & r & $v$ & & & & & & & & & & 0 \\
\hline Phannatiq & & & & & & & & & $\checkmark$ & $\checkmark$ & & & 0 & & & 0 \\
\hline People Tree & $\checkmark$ & $\checkmark$ & & & & & & & & $\checkmark$ & & & 0 & & 0 & \\
\hline Pottie Lottie & & & & & & & $\checkmark$ & & & & & & & & & \\
\hline Prophetik & $\checkmark$ & $\checkmark$ & & & & & & & & & & & & & 0 & \\
\hline Reet Aus & & $\checkmark$ & & & & & & & & & & & & & 0 & \\
\hline RITA HRAIZ IN & & $\checkmark$ & & & & & & & & & & & & 0 & & 0 \\
\hline Rudá Rings & & & & & & & & & $\checkmark$ & & & & & & $\circ$ & \\
\hline Samant Chauhan & & $\checkmark$ & & & & & & & & & & & & 0 & & \\
\hline Sonya Kashmiri & & & & & & & & & & $\checkmark$ & & & 0 & & & \\
\hline STEWART+BROWN & & $\checkmark$ & & & & & & & & & & & & & o & $\circ$ \\
\hline Study NY (Tara St. & & & & & & $v$ & $\checkmark$ & & & & & & 0 & & & \\
\hline Termite & & & & & & & & & & & & & 0 & & 0 & \\
\hline Terra Plana & a & & & & & & & & & & & & & & 0 & 0 \\
\hline The North Circular & & $\checkmark v$ & $\checkmark$ & $\checkmark v$ & 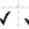 & $v$ & $v$ & & $\checkmark$ & & & & 0 & 0 & & 0 \\
\hline Veja & & $\checkmark$ & & & & & & & $\checkmark$ & & & & & 0 & & 0 \\
\hline Victim Fashion Street & & & & & & & & $\checkmark$ & & & & & & & 0 & \\
\hline White Tent & & & & & & & & $\checkmark$ & & & & & & 0 & & \\
\hline Wool and the Gang. & & & & & & & & & & & & $\checkmark$ & 0 & & & 0 \\
\hline
\end{tabular}




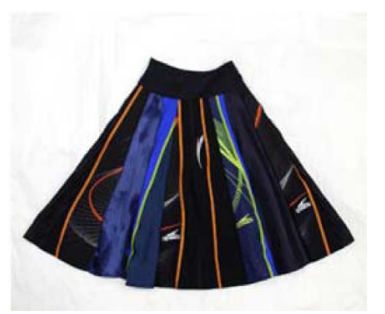

Fig. 1. From Somewhere and Speedo collaboration dress. fromsomewhere.co.uk.

From Somewhere has, since then, made clothes such as dresses and leggings by using these high-tech swimsuits and fabric (Fig. 1). This shows the possibilities of utilizing one company's excess stock by collaborating with other companies instead of throwing it away.

Bottletop collaborates with famous fashion houses to produce bags hand-made from tin bottle tops by a small Brazilian women's community. From collecting raw soda can tabs since 2002, they have now evolved into makers of trendy items (Bottletop, 2014). In February 2014, Bottletop collaborated with American fashion designer Narciso Rodriguez and produced bags exclusively for Harrods UK. In SS 2015, it struck a successful collaboration with the famous fashion house $D K N Y$ (Fig. 2).

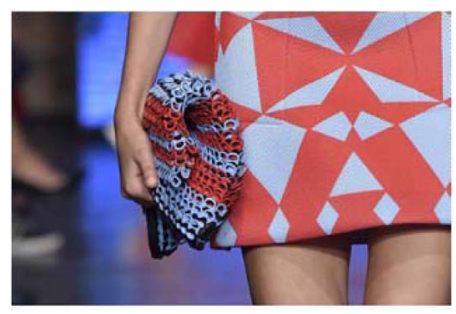

Fig. 2. The DKNY (Heart) Bottletop SS Collection. bottletop.org.

Honest by. Bruno Pieters has made an unprecedented attempt in the fashion industry; transparency in price, material and manufacturing. In an interview with Wild magazine Pieters explained that 'there are a lot of brands that claim to be responsible, but the information they offer is so vague it's almost offensive. Also, if what you're doing is really that good why not share it and show it to the world?' (Ozeri \& Kirkpatrick, 2014). Full transparency of origin and pricing is achieved by exposing everything that is used in the garment making process, from raw material to working time and the costs involved at each stage (Fig. 3). As these are normally hidden, by exposing them the designer can establish trust with customers. Not only are the garments made responsibly but also customers can understand garment pricing, the amount of which can sometimes be regarded as excessive when production costs are

\section{Material information}

\section{Product code: BPW01552310U} Product description: QUILTED OVERSIZED SLEEVELESS JACKET

FABRICS

Fabric upper part: featherweight wool tartan tweed Composition: $100 \%$ wool

Weight: 470 gr/mYarn or piece dyed: loose wool dyed (different types of wool are blended together and dyed before being twisted into yarn)

Origin of raw material: Scottish border, UK

Spinner: Harris Tweed Hebrides, Shawbost Isle of

Lewis, Scotland

Weaver: Calum Macleod, Stornoway, Isle of Lewis

(hand woven in his own home)

Dyer/Finisher: Harris Tweed Hebrides, Shawbost Isle of

Lewis, Scotland

Supplier: Harris Tweed Hebrides, Shawbost Isle of

Lewis, Scotland

unw. harristweedhebrides.com

\section{Price calculation}

Product code: BPW01552310U Product description: QUILTED OVERSIZED SLEEVELESS JACKET

FABRICS

Fabric upper part: featherweight wool tweed

Composition: $100 \%$ virgin wool

Price / Meter: 21,74 Euro

Amount used: 0,53 Meter

Total: 11,52 Euro

Fabric lower part: white cotton satin

Composition: $98 \%$ organic cotton, GOTS certified, $2 \%$ EA

Price / Meter: 7,05 Euro

Amount used: 0,55 Meter Total: 3,87 Euro

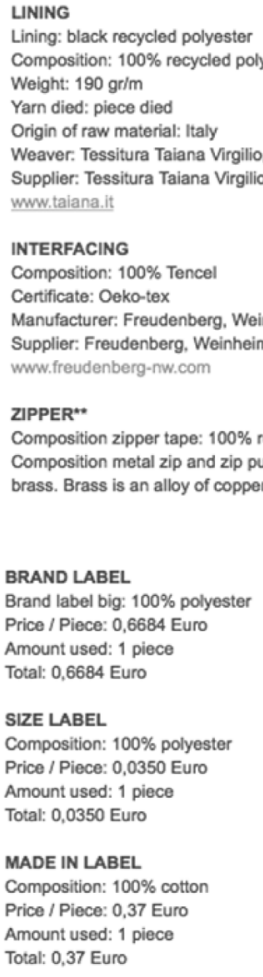

MADE IN LABEL

Composition : $100 \%$ cotton

Manufacturer: Van Campenhoudt, Schaarbeek, Belgium Supplier: Van Campenhoudt, Schaarbeek, Belgium

CARE LABEL**

Composition : $100 \%$ polyester

Manufacturer: Van Campenhoudt, Schaarbeek, Belgium Supplier: Van Campenhoudt, Schaarbeek, Belgium

SECURITY SEAL

Composition : $100 \%$ polystyrene

Certificate: ISO 18001,certified manufacturer

Origin of raw material: ttaly

Manufacturer: UNISTO, Italy

Supplier: UNISTO, Italy

unw.unisto.it

HANG TAG

Composition: $100 \%$ recycled paper

Origin of raw material: Europe mainly Germany

SAFETY PIN

Composition: nickel free metal

Price / Piece: 0,03 Euro

Amount used: 1 piece

Total: 0,03 Euro

TOTAL MATERIAL COSTS: 50,62 EURO

MANUFACTURING COST

Garment manufacturing: 102 Euro

COLLECTION COST: 10,30 Euro

The collection cost covers the development of the new collection, pattern making costs, grading, digitizing, purchasing of fabrics and trimmings and branding costs.

TOTAL COST: 162,92 EURO

Fig. 3. Sections from a website detailing the materials relative to a product and its price at each stage. honestby.com. 
transparency shows new possibilities in ethical fashion making.

\subsection{Outstanding events in Estethica}

From its beginning in 2006, Estethica has supported upcoming designers in the competitive fashion industry through mentoring services. The British Fashion Council, organiser of LFW, has devised a scheme involving mentors for selected emerging ethical design businesses: in AW 2011, out of 22 Estethica participants, 5 design businesses (Christopher Raeburn, From Somewhere, Junky Styling, Lu Flux and The North Circular) were selected by industry experts to be advised on marketing, branding, promoting, and producing (The British Fashion Council, 2011). Orsola de Castro, cocurator of Estethica, designer and founder of the sustainable brand From Somewhere, says, 'Estethica nurtured eco fashion from its infancy and has helped launch it into the stratosphere' (ibid.). This Estethica mentoring system relates to education, marketing consultancy, business direction and PR opportunities. Through this mentoring service, young designers such as Ada Zanditon and Christopher Raeburn have strengthened their business and are successfully stocked in high-end boutiques in UK, Europe, America and Asia.

Estethica is now exhibiting together with other LFW ready-towear and accessories by using its own tag (Fig. 4). Until AW 2014, its brands used to be displayed in a separate showroom space at Somerset House (where LFW is held). Caroline Rush, Chief Executive of the British Fashion Council, comments that 'the new Estethica tag aims to recognise that fashion and sustainable fashion can be one and the same thing' (The British Fashion Council, 2014a). Thus, Estethica brands are now considered good enough to

\section{B R I T I SH FA SH I ON COUNCIL estethica \\ FASHION FOR A SUSTAINABLE FUTURE}

Fig. 4. The Estethica Tag. thebritishfashioncouncil.co.uk.

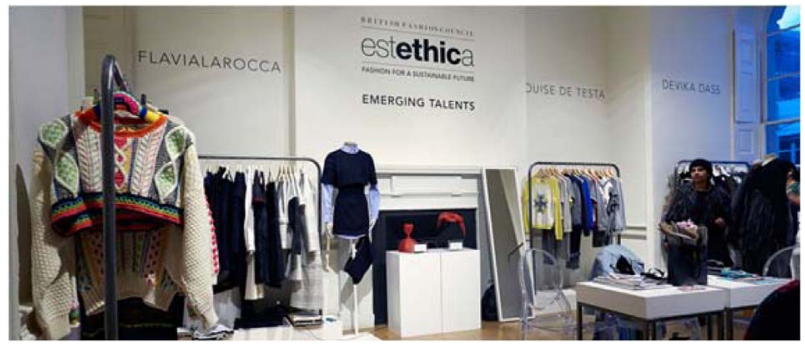

Fig. 5. The Emerging Talents Showroom for new designers (September 14, 2014). compete with big fashion names without needing any 'sustainability' label. From 2013, however, emerging brands in need of support (Flavia La Rocca, Katie Jones, Louise De Testa and Wool and the Gang) now show separately in the 'Estethica Emerging Talents Showroom' (Fig. 5), where curator Orsola de Castro mentors the new design talents (ibid.).

\section{Sustainable Characteristics and Trends in Estethica}

Some characteristics are emerged from an analysis of Estethica brands and events. Firstly, upcycling suggests the extension of a product's lifecycle, a trend on the increase. A garment's lifecycle is normally equated to its making process from raw material and design to production, packing and transportation, consumer use and end of life (Table 1). This used to be a straight linear process; however, recycling, reuse and upcycling turn the direction back into material state and the birth of a new product, so the lifecycle becomes circular: material, fashion items, waste, a new material and fashion items again. Because existing material is used, new material becomes unnecessary, which means saving on natural resources and avoiding the pollution caused by the early stages in the making process. This also reduces waste. The new upcycling industry needs leftovers or throwaway material. So it is unavoidable to collaborate with fashion companies or other relevant material-using companies that produce leftover fabrics or materials during the making process. One notable example is the above-mentioned collaboration between FromSomewhere and Speedo. Thus, upcycling suggests new forms of industry that help one another in order to enable the circulation of their products. Although this is one-off pop-up events, a multi-media artist, Alex Noble created Tshirts using leftover materials from British designers participating in LFW and London Collection: Men including Agi \& Sam, Giles Deacon, Kit Neale, Louise Gray and Zandra Rhodes (Fig. 6), and the EMG (Everything Must Go) installation in SS 2015 LFW (ibid.). This has been effective in letting visitors to LFW (such as buyers and the press) know about the worth of leftovers.

Transparency is the second crucial issue in sustainable fashion. Sustainable ethical trading exposes people involved in farming and materials making, so any unfair labour conditions and unbalanced economic development can become known to the general public. This urges producers to act more responsibly. In Sustainable Fashion and Textiles, Fletcher (2008) proposes the 'user maker' as a model of action: by getting involved in the making, the user gets a better knowledge of the actual process. This makes users acknowledge the importance of ethical making, cherish the finished product more and use it longer. The Wool and the Gang brand encourages 


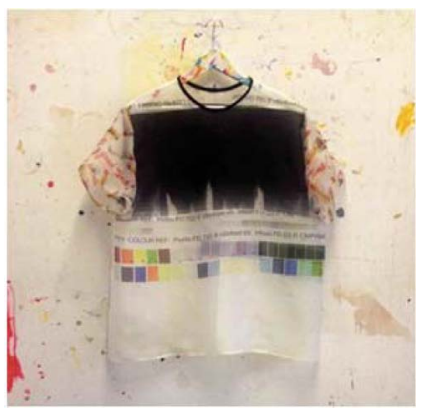

Fig. 6. Alex Noble's SS 2015 EMG pop-up event. traid.org.uk.

the participation of wearers by knitting their own garments; posting garment patterns and providing tutorials on their website (Fig. 7). Wearers thus share patterns and skills that used to be the makers' own. However, this transparency in making can be further stretched to transparency in the origin and price of making, as attempted by Honest by. Bruno Pieters. When there is more transparency, users can know and trust more and relate more: they become part of the fashion process and have more responsibility in sustainable fashion practice.

Thirdly, Estethica shows that nurturing sustainable brands is one effective way of boosting the sustainable industry, as well as encouraging the production of sustainable products. As seen in Table 2, many brands are young when attending Estethica. Among 80 brands, around $70 \%$ are established after 2007 . There are some exceptions; an established brand such as Michelle Lowe Holder, launched in 2001, turned towards an ethical approach after acknowledging the importance of sustainability in the fashion industry in 2009. However, the fact that most brands have launched their business under Estethica's ethical aspiration. For any new business, every stage, from funding, brand identity, team building, suppliers, to manufacturing, marketing, sales, PR, showcasing is a challenge. Estethica's supporting programme not only sustains individual brands but also assists young designers, such as Christopher Raeburn, towards becoming star brands. It works as sustainable fashion acknowledged by more people who sell their stock internationally. Brands supported by Estethica boost the sustainable fashion industry and spread its message.

Fourthly, sustainable fashion has come to be included in mainstream fashion in terms of aesthetics and commercial competitiveness. Until the mid-2000s, it emphasised ethics rather than aesthetics. David Shah, the fashion designer, trend watcher and moderator at the Beyond Green fashion symposium, pointed out that 'everybody was in eco fashion looked like a bag of potatoes' (Brand, 2008). In fact, because more weight used to be attributed to sustainability itself, fashionable aesthetics or commodity value were underestimated in sustainable fashion.

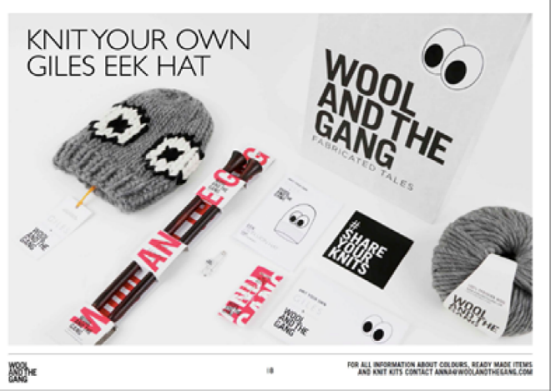

Fig. 7. Wool and the Gang tool kit for the user maker. woolandthegang.com.

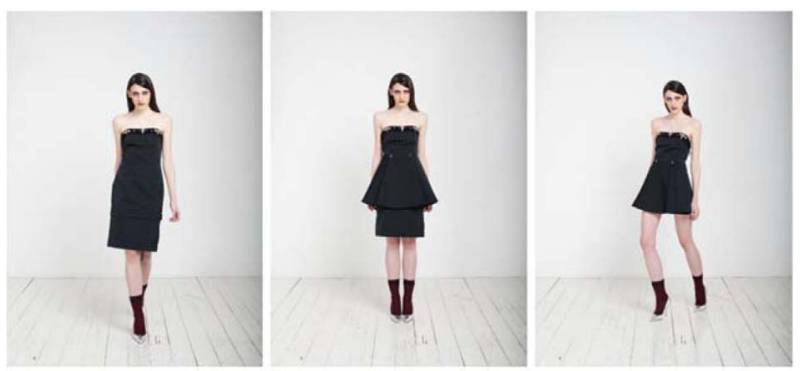

Fig. 8. Flavia Larocca's modular dress. flavialarocca.com.

Nowadays, however, many sustainable garments satisfy ethical concerns as well as the eye. Speaking of upcycling, sometimes it is hard to notice that they are made of recycled or reclaimed materials. The expression 'upcycled fashion' has in fact been coined to upgrade their image (Kay, 1994). This changing attitude can be seen by the fact that Estethica brands are now integrated into other ready-to-wear and accessories showrooms with their attached Estethica tags. Estethica designer Katrien van Hecke says that 'sustainability is the new high fashion' (The British Fashion Council, 2014b).

Lastly, sustainable fashion highlights quality of garments. Sustainability includes care about working conditions, the environment and the future life of human beings. Also, 'sustainability' is shorthand for the highest possible effectiveness of good-quality, longlasting garments. High quality and satisfactory design make wearers wear a garment longer, thus lengthening its lifespan, just as upcycling does. Also, wearing a garment in different ways (such as a jacket turning into a dress) reduces the number of garments one needs. Italian designer Flavia Larocca makes modular garments by which users can create different types of looks according to taste or occasion (Fig. 7, 8).

\section{Conclusion}

Sustainability has now become an important issue. A pioneer in sustainability, the UK set up Estethica in LFW, a leading trade 
showcase for the latest fashion trends, with a large international audience and strict sustainability criteria.

This research aims to analyse the current sustainable fashion trend and defines its characteristics through Esthetica, a brand that helps direct and plan the future of fashion sustainability. Through the analysis of brands and events from SS 2009 to SS 2015, there emerges that the Estethica brand has been using diverse ethical methods, such as promoting upcycling as a way of extending a product's lifecycle to counter excessive waste and environmental damage; encouraging collaboration for sourcing; creating new types of industry which can work together. Transparency in price, material, labour and skills is an effective way of making fashion brands sustainable; this involves wearers too in fashion practice. In addition, Estethica shows that nurturing sustainable brands in their early business stages boosts the sustainable industry. Sustainable fashion is now mainstream in terms of fashion aesthetics, with Estethica as a trendsetter. Not only material and manufacturing methods but also design and garment quality can be crucial to sustainable fashion.

Thus, sustainable fashion is not only a trend but a lifestyle too. It is not just a suggestion for fashion industry manufacturers to include upcycling, collaboration, transparency, nurturing, quality control; it also provides guidelines for consumers to help expanding a product's lifecycle by choosing good quality products, including upcycled ones. Sustainable fashion, therefore, is not only a business model. Estethica shows the present of sustainable fashion and its future direction through its brands and events. It also shows that sustainable fashion has now acquired great influence as a trend, despite its "unfashionable" origin in ethical making and consuming.

This study has considered sustainable fashion in terms of ethics, fashion trends, commercial competitiveness and contribution to the sustainable industry. As the sustainable industry is a growing sector, it would be useful to carry out separate in-depth case studies on leading sustainable brands to inform the direction of future sustainability. It would also be interesting to study the emotional and psychological aspects of sustainable fashion as affecting quality. Such studies would help forecast and understand the future of fashion by covering its commercial, environmental and personal aspects.

\section{References}

Brand, J. (2008). Beyond Green: Sustainability and Fashion: Progress in Fashion and Sustainability. Arnehm: ArtEZ Press.

'Bottletop'. (2014). Bottletop News. Retrieved October 1, 2014, from http://bottletop.org/blogs/news

Borrini-Feyerabend, G., Pimbert, M., Farvar, T, Kothari, A., Jaireth, H.,
Murphree, M., Pattemore, V., Ramrez, R., \& Warren, P. (2007). Sharing Power: A Global Guide to Collaborative Management of Natural Resources. Oxford: Earthscan.

Brough, D. (2008). 'Briton finds ethical jewellery good as gold'. Reuters Canada. Retrieved September 30, 2014, from http://ca. reuters.com/article/oddlyEnoughNews/idCAL213911220080110

Carson, R. (1964). Silent Spring. Minnesota: Fawcett publication Inc.

Centre for Sustainable Fashion at the London College of Fashion (2008). Fashion \& Sustainability, A Snapshot Analysis (Volume 1.0). London: London College of Fashion.

'Charini'. (2014). Charini Press Release. Retrieved November 1, 2014, from http://www.londonfashionweek.co.uk/uploads/documents/ doc_3325.pdf.

Choi, Y. J., \& Kim, D. H. (2012). Fashion jewellery development direction through upcycle. Proceeding of the Korean Contents Association Conference, pp. 317-318.

'Co-operative Bank'. (2010). The co-operative bank's annual ethical consumerism report. Retrieved October 10, 2014, from http:// www.goodwithmoney.co.uk/ethical-consumerism-report-2010.

DEFRA. (2010). Sustainable clothing action plan led by DEFRA, the Department for Environment, Food and Rural Affairs. Retrieved September 23, 2014, from https:/www.gov.uk/government/uploads/ system/uploads/attachment_data/file/69193/pb13206-clothingaction-plan-100216.pdf

Farrer, J. (2011). "Remediation: discussing fashion textiles sustainability" in Shaping sustainable fashion: changing the way we make and use clothes. London: Earthscan.

'Flavialarocca'. (2014). Flavialarocca main page. Retrieved November 13, 2014, from flavialarocca.com

Fletcher, K. (2008). Sustainable Fashion \& Textiles: Design Journeys. Oxford: Earthscan.

Friedman, V. (2014). 'Dinner WITH THE FT: Anya Hindmarch'. Financial Times. Retrieved December 12, 2014, from http://www. ft.com/cms/s/2/5cfffofe-1479-11e3-84b4-00144feabdc0.html

'Fromsomewhere'. (2014). Panel Skirt. Retrieved November 13, 2014, from http://fromsomewhere.co.uk/shop/panel-skirt/black-7

Retrieved October 13, 2014, from http://www.honestby.com/en/ product/27/dresses/black-cotton-wrap-shirt-dress.html

Hong, Y. M., \& Kim, Y. J. (2014). Attitudes of the Korean college students toward upcycle fashion product. The Journal of Korean Society of Design Culture, 20(2), 207-218.

Jeong, Y. R. (2012). A study on upcycle redesign using waste in fashion goods industry: Focused on the reuse of industrial waste. Unpublished master's thesis, Ewha Womans University, Seoul.

Kay, T. (1994). 'Salvo in Germany - Reiner Pilz', SalvoNEWS (99), 14. Retrieved October 5, 2014 from http://www.salvoweb.com/files/ salvonews/sn99v3.pdf

Kim, J. K. (2013). A study on the brand activation strategy for the recycle design. The Journal of Brand Design Association of Korea, 11(1), 53-66.

Kim, S. H., \& Lee, J. J. (2006). The concept of sustainable fashion design and the principles. The Journal of Korean Society of Basic Design and Art, 7(3), 223-237.

Kim, S. H. (2007). A study on the sustainable design in contemporary fashion: Focused on the case study in UK. Unpublished doctoral dissertation, Dan Kook University, Seoul.

Kim, S. H., Lee, J. J., \& Jeong, H. S. (2007). A study on the 
sustainable fashion design by organic cotton. Journal of the Korean Society of Costume, 57(2), 115-131.

Kwan, J. S. (2012). Based on the perspective of sustainability, the characteristics of upcycle fashion design. Fashion and Textile Research Journal, 14(1), 13-23. doi:10.5805/KSCI.2012.14.1.013

McDonpugh, W., \& Braungart, M. (2002). Cradle to Cradle: Remaking the way we make things. New York: North Point Press.

Nam, M. K. (2011). A study on developing policy and stategy for sustainable global eco-friendly product design. The Journal of Korean Society of Design Culture, 17(3), 185-195.

Niinimaki, K., \& Hassi, L. (2011). Emerging design strategies in sustainable production and consumption of textiles and clothing. Journal of Cleaner Production, 19(16), 1876-1883.

'Oxfam'. (2014). 'History of Oxfam', Oxfam Organisation. Retrieved October 28, 2014 from http://www.oxfam.org.uk/what-we-do/ about-us/history-of-oxfam

Ozeri, B., \& Kirkpatrick, E. (2014). 'An interview with Bruno Pieters of Honest by', Wild Magazine. Retrieved October, 24, 2014 from http://thewildmagazine.com/blog/an-interview-with-bruno-pietersof-honest-by/

Pears, K. (2006). Fashion re-consumption: developing a sustainable fashion consumption practice influenced by sustainability and consumption theory. Unpublished master's thesis, RMIT University, Austrailia.

'PicassoMio'. (2014). Green Design: Design for the Environment. piccassomio.com. Retrieved October 7, 2014, from http://www. picassomio.com/architecture-and-design/green-design-design-forthe-environment.html

Runice, C. (2014). 'An Inconvenient Truth 2: even more inconvenient?'. Telegraph. Retrieved November 13, 2014, from http://www.telegraph. co.uk/culture/film/film-news/10741640/An-Inconvenient-Truth-2even-more-inconvenient.html

Sahni, H. (2009). Fashion and Well being. London: IFFTI.

Sander, K., Tojo, N., \& Vernon, J. (2007). 'The Producer Responsibility Principle of the WEEE Directive'. europa.eu. Retrieved November 23, 2014, from http://ec.europa.eu/environment/waste/weee/pdf/ final_rep_okopol.pdf

Smith, C., \& Rees, G. (1998). Economic Development. Basingstoke: Macmillan.
The British Fashion Council. (2008). The Sustainable Thread of a Product Lifecycle. Retrieved October, 28, 2014 from http:// britishfashioncouncil.com/uploads/media/290/19862.pdf

The British Fashion Council. (2011). Esthetica AW 11 at the Exhibition. Retrieved September 22, 2014, from http://www.londonfashionweek. co.uk/news detail.aspx?ID $=280$

The British Fashion Council. (2014a). 'London Fashion Week Esthetica Press release'. Retreived October 5, 2014 from http:// www.britishfashioncouncil.co.uk/pressreleases/Estethica-AW14.

The British Fashion Council. (2014b). 'Sustainable Fashion at London Fashion Week SS15'. Esthetica Press release. Retrieved October 17, 2014, from http://www.britishfashioncouncil.co.uk/pressreleases/ Sustainable-Fashion-at-London-Fashion-week-SS15

'The Zero Waste International Alliance'. (2004). 'Zero Waste Definition'. Retrieved April 18, 2015, from http://www.zwallianceuk.org/ wpzw01/wp-content/uploads/ZWIA-Peer-reviewed-Definition.pdf

'Traid'. (2014). EMG Pop Up Launch. Retrieved December 7, 2014, from www.traid.org.uk/emg-pop-up-launch/

'United Nations Division for Sustainable Development'. (1992). 'Agenda 21'. Retrieved November 25, 2014, from https:// sustainabledevelopment.un.org/content/documents/Agenda21.pdf

Woodham, J. (2010). Formulating National Design Policies in the United States: Recycling the 'Emperor's New Clothes'? Design Issues, 26(2), 27-46.

Wool and the Gang tool kit for the user maker. (n.d.). Retrieved November 28, 2014, from www.woolandthegang.com.

Yoo, H. S. (2012). Ethical fashion in the fashion industry -Focusing on the actualization of sustainable fashion. Journal of the Korean Society of Fashion Design, 12(2), 39-57.

Yoon, S. I. (2013). (A) study on the current status of sustainable fashion industry and consumer's consumption behavior: Focused on reused and recycled fashion industry. Unpublished doctoral dissertation, Dan Kook University, Seoul.

(Received 27 January 2015; 1st Revised 16 April 2015; 2nd Revised 20 April 2015; Accepted 27 April 2015)

C 2015 (by) the authors. This article is an open access article distributed under the terms and conditions of the Creative Commons Attribution license (http://creativecommons.org/licenses/by/3.0/), which permits unrestricted use, distribution, and reproduction in any medium, provided the original work is properly cited. 